\title{
Regenerative Properties of Recombinant Human Erythropoietin in the Wound Healing
}

\author{
Medet Toleubayev ${ }^{1,2 *}$, Mariya Dmitriyeva ${ }^{1}$, Saken Kozhakhmetov ${ }^{1}$, Nurbek Igissinov $^{1}$, Dulat Turebayev ${ }^{1}$, Ardak Omarbekov $^{1}$, \\ Kairat Adaibayev ${ }^{1}$, Abylay Shakenov ${ }^{1}$, Mirsaid Izimbergenov ${ }^{1}$ \\ ${ }^{1}$ Department of Public Health, Medical University of Astana, Nur-Sultan, Republic of Kazakhstan; ${ }^{2}$ Department of Surgery, \\ Multidisciplinary city Hospital No. 1, Nur-Sultan, Republic of Kazakhstan
}

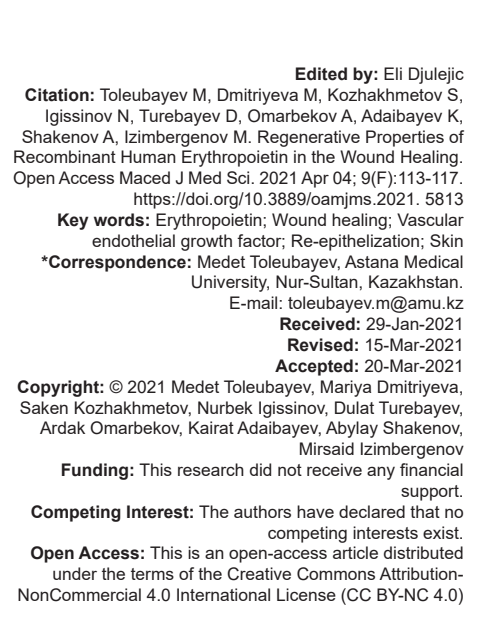

\section{Abstract}

BACKGROUND: Erythropoietin (EPO) is the main stimulator of erythropoiesis, but EPO also has non-hematopoietic effects. The recent data show the positive effects of EPO on tissue regeneration.

AIM: This review aims to know highlights the pathophysiological mechanisms of EPO at different stages of tissue regeneration, and possible clinical applications in wound healing.

METHODS: A review of the literature considering reviews, clinical studies, original papers, and articles from electronic data has been used.

RESULTS: Analysis of animal studies and several clinical trials using EPO in context of wound healing revealed that EPO has a positive effect on all stages of regeneration process and may be a promising therapeutic strategy for the treatment of chronic wounds.

CONCLUSION: An improved understanding of the functions and regulatory mechanisms of EPO in the context of wound healing may lead to new considerations of this growth hormone for its regular clinical application in patients.

\section{Introduction}

Recombinant human erythropoietin (EPO) is a glycoprotein hormone that belongs to the hematopoietic cytokines. It is responsible for controlling the mass of red blood cells, provoking the proliferation, and differentiation of progenitor cells and inhibiting the programmed death (apoptosis) of erythroid cells in the bone marrow, but the role of EPO in the healing of skin wounds is also being studied [1], [2], [3]. EPO has a number of functions other than hematopoietic. EPO receptors are found not only on the erythroid elements of the bone marrow but also on the cells of the nervous tissue, ovaries and testes, uterus, vascular smooth muscle cells, cardiomyocytes, endotheliocytes, epithelium of the lungs and renal tubules, and other cells [4]. Considering that EPO receptors are expressed on endothelial cells, macrophages, fibroblasts, mast cells, melanocytes, and hair follicles, it has been suggested that EPO is able to accelerate the regeneration of skin wounds by stimulating angiogenesis, the formation of extracellular matrix and collagen, as well as limiting inflammatory mediators and apoptosis [5], [6], [7], [8]. The increasing importance of
EPO is represented by its non-hematopoietic action of interest for regenerative medicine, moreover its ability to enhance wound healing.

\section{Influence of EPO on Pathophysiological Regeneration Process}

Below is an overview of the pleiotropic spectrum of activity of the glycoprotein hormone EPO in the treatment of experimental wounds (Table 1). In a recent study by Hamed et al. studied the ability of high doses of EPO to influence the healing of burn wounds in diabetic. It was found that EPO accelerates the healing of burns by activating angiogenesis, triggering collagen synthesis and the formation of extracellular matrix, and also stimulates re-epithelialization by keratinocytes [9].

Growth factors play an important role in tissue regeneration, for example, transforming growth factor (TGF)-b is one of the main modulators of wound healing, capable of enhancing fibroblast proliferation, 
Table 1: Studies investigating the use of EPO for the treatment of experimental wounds

\begin{tabular}{|c|c|c|c|c|c|c|}
\hline Authors & Wound type & Species & EPO dose IU $/ \mathrm{kg}$ bw & Mode of administration & Duration of administration in days & Enhance healing \\
\hline \multirow[t]{2}{*}{ Hamed [9] } & burns & pigs & 2000 & $s / c$ & 14 & $\Delta$ \\
\hline & burns & pigs & 500 & $i / v$ & 14 & $\Delta$ \\
\hline Siebert [10] & full-thickness wounds & mice & 5000 & $i / v$ & $12 \mathrm{gH}$ & $\Delta$ \\
\hline Javadmoosavi [11] & full-thickness wounds & mice & 500 & $i / v$ & 14 & $\boldsymbol{\Delta}$ \\
\hline Sayan [12] & full-thickness wounds & mice & 500 & $s / c$ & 7 & $\Delta$ \\
\hline Bader [13] & Burns & mice & 500 & $\mathrm{~s} / \mathrm{c}$ & 14 & $\Delta$ \\
\hline Erbayraktar [14] & Infected wounds & rats & Karbamyl-ЭПО 10 mg/kg bw & $i / v$ & 8 & $\Delta$ \\
\hline Hamed [18] & Diabetic wounds & mice & 3000 & topical & 12 & $\Delta$ \\
\hline Imam [19] & burns & rats & 500 & $\mathrm{~s} / \mathrm{c}$ & 21 & $\boldsymbol{\Delta}$ \\
\hline Galeano [20] & burns & mice & 400 & $\mathrm{~s} / \mathrm{c}$ & 14 & $\Delta$ \\
\hline
\end{tabular}

extracellular matrix deposition, and angiogenesis. In an experimental study by Siebert, the introduction of EPO accelerated the epithelialization of wounds and induced the expression of TGF-b1 in mice [10].

According to the results of another study in mice, conducted by Javadmoosavi et al., there was a decrease in the inflammatory response in the wounds treated with EPO systemically compared to the group with subcutaneous administration of EPO and the control group. Moreover, in the EPO-treated groups, there was an increase in the number of fibroblasts in wounds and an acceleration of angiogenesis [11]. Sayan et al. presented a study that examined the effect of EPO administration in mice with full-thickness wounds to analyze wound tear strength and vascular endothelial growth factor (VEGF) expression. The results demonstrated better tissue re-epithelialization, significantly increased tensile strength, higher collagen, and VEGF content in wounds [12]. Bader et al. studied the topical application of EPO for the treatment of burns in mice, the results showed statistically significant faster wound healing and re-epithelialization, improved proliferation of the extracellular matrix, and increased angiogenesis with high VEGF levels [13]. One study by Erbayraktar examined the role of EPO in various models of wound healing, such as chronic ischemic wounds, traumatized wounds, and infected wounds. EPO was able to significantly reduce the inflammatory response and accelerate the regeneration of blood vessels in healing skin [14].

Skin regeneration is regulated by vertical migration and differentiation of stem cells originating from hair follicles. Hair follicles are among the cells with the highest cellular turnover in the human body and thus were the basis of the next study, in which the human hair follicle was first considered as a nonrenal source of EPO synthesis. This study showed that the outer root layer of growing hair follicles and newly developed blood vessels of the skin were able to synthesize EPO and induce apoptosis in the hair follicle [15]. In this context, Paus et al. further suggested that the skin may play a much more important role in EPO synthesis than previously thought. It was found that the skin directly affects the levels of EPO in the blood plasma in an order corresponding to the level of hypoxia in the dermis. Moreover, the skin, as the largest organ of the human body, can compensate for the insufficient synthesis of EPO in conditions of renal failure [16]. A study by Buemi et al. demonstrated that on the regenerated tissue of ischemic wounds in rats, EPO administration was associated with increased VEGF expression, thus increasing the density of newly formed microvessels, as well as a higher density of collagen fibers [17]. In addition, EPO was able to accelerate wound healing in diabetic mice, which was manifested in an increase in the rupture strength of the scar compared to the control, which correlated with the induced overexpression of VEGF [18]. In a study by Hamed et al. analyzed the local effect of EPO on the wounds of diabetic rats. Reported EPOinduced VEGF production was associated with an increased angiogenic response and improved delivery of oxygen and nutrients to the wound [19]. In the Imam study, burns in rats were treated with EPO with mesenchymal stem cells, and a histological picture of improved epithelialization was noted, although differentiation of stem cells into keratinocytes was not always detected by infrared fluorescence, it was also found to a significant increase in immunoexpression of VEGF compared with the control group, probably due to the anti-inflammatory, immunomodulatory, and angiogenic effects [20]. Galeano et al. in their study also examined the effect of EPO on deep seconddegree skin burns in mice. A significant acceleration of wound epithelialization associated with improved maturation of the extracellular matrix, an increased rate of formation of new microvessels, and an increased rate of epithelial cell proliferation were noted [21].

To date, the function of hematopoietic receptors in wound healing has not been studied. Furthermore, the use of EPO can have side effects due to its effect on hematopoietic receptors, which can lead to thrombosis [22]. To circumvent these problems, new compounds have been developed that have specificity for innate tissue repair receptors (IRR) [23]. For example, cibinetide is an 11 amino acid IRR peptide agonist that has been studied in a large number of preclinical studies [8]. These results indicate the need for studies to evaluate the clinical efficacy of cibinetide in tissue regeneration. Table 1 presents studies examining the use of EPO for the treatment of experimental wounds.

Thus, EPO-mediated increased wound healing capacity may be associated with the following mechanisms: First, EPO is an angiogenic factor leading to a mitogenic response of endothelial cells. The formation of new functional capillary structures 
includes activation, migration, proliferation of endothelial cells, maturation of intercellular junctions, and the surrounding basement membrane. Each of these phases is influenced by VEGF, which has also been described synergistically with EPO for neovascularization and angiogenesis [17], [18]. Second, successful tissue repair includes both the formation of granulation tissue in the early stages of wound healing and its remodeling at later stages of regeneration. The use of EPO was associated with an accelerated remodeling of granulation tissue, which is due to the lower cellularity of the wound contents and, especially, the lower levels of inflammatory cells. Moreover, human leukocytes and monocytemacrophage cell lines have shown that EPO is able to inhibit the production of pro-inflammatory cytokines and TNF- $\alpha$ [10], [21]. Third, the anti-apoptotic environment created by EPO can further improve wound healing ability. Accordingly, endogenous delivery of EPO to the area immediately surrounding damaged tissues can reduce the death of apoptotic cells by inhibiting the activity of inflammatory cells and suppressing the production of pro-inflammatory cytokines, including TNF- $\alpha$ [2]. Fourth, changes in the rheology of blood cells due to an increase in the mass of erythrocytes and leukocytes were important features of the use of EPO. In this context, more efficient delivery of oxygen to the tissues due to the increased mass of red blood cells can lead to accelerated cell growth. EPO data, which did not show any increase in hematocrit or hemoglobin, with improved healing ability, indicate hematopoietic independent tissue protection mediated by this hormone [24], [25]. Taken together, there is a sufficient amount of experimental data confirming the effectiveness of EPO on the pathomorphological processes of skin wound healing, but it is still impossible to determine a single mechanism or cellular function that could be responsible for the ability of tissue regeneration mediated by EPO.

\section{Premise for Using EPO for Wound Healing}

The introduction of EPO into everyday clinical practice about 25 years ago not only revolutionized the treatment of anemia but also became a new area of research related to its non-hematopoietic properties. To date, extensive studies describe the interaction of EPO with various cells, which is not limited to the production of red blood cells. However, the use of EPO as a nonhematopoietic agent in daily clinical practice is still very limited. One of the reasons may be based on the fact that the pleiotropic effects of EPO open up new therapeutic possibilities that have not yet been clinically proven. The use of EPO to accelerate skin regeneration is based on the following mechanisms of its influence at all stages of regeneration (Figure 1):

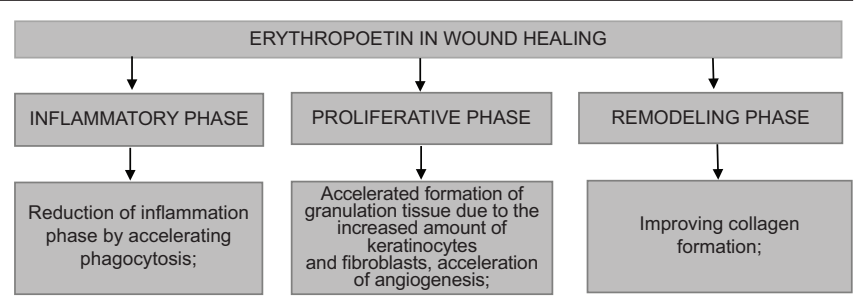

Figure 1: Effects of Erythropoietin on skin wound healing

There is a positive effect on all phases of wound regeneration. Reducing the phase of inflammation is associated with increased phagocytosis, which reduces the inflammatory response in wounds and has a positive effect on healing; the accelerated formation of granulation tissue during the proliferation phase in EPO-treated wounds is most likely the result of three different effects: EPO improves cell motility and thus increases the rate of migration, especially in keratinocytes and fibroblasts, resulting in faster wound closure. During the proliferation stage, an increased angiogenic response, accelerated microvascular formation and improved maturation are associated with improved nutrition and metabolism of the wound and the environment. In the stage of remodeling, an increase in the content of collagen fibers in the wound is noted. In this context, there are few clinical studies that have examined the efficacy of EPO for wound healing (Table 2). In a randomized clinical trial (RCT) Chatzikyrkou et al. studied the regenerative effects of EPO in diabetic ulcers, noted better healing compared to controls. It is noted that the administration of low doses of EPO improves wound healing in patients with diabetes without affecting the hematocrit level [26]. In RCTs, Guenter EPO was used to treat burns [27]. However, the results (epithelialization of burn wounds) were inconclusive. Hamed et al. used topical EPO treatment of diabetic ulcers in the description of a series of cases, and noted a significant improvement in wound healing, compared with controls [28]. In a series of cases of Ferri, EPO was used to treat skin ulcers in systemic scleroderma; an improvement in epithelialization was noted with intradermal application [29]. In another study of a series of Giri cases, EPO treatment was given to three patients with diabetic ulcers, and the treatment showed an improvement in tissue regeneration [30]. In a case series study of Keast EPO was used to treat pressure ulcers in anemic patients, resulting in improved tissue epithelialization [31].

Table 2: Studies investigating the use of EPO for the treatment of chronic wounds

\begin{tabular}{|c|c|c|c|c|c|}
\hline Authors & $\begin{array}{l}\text { Wound } \\
\text { types }\end{array}$ & $\begin{array}{l}\text { EPO dose } \\
\text { IU/kg bw }\end{array}$ & $\begin{array}{l}\text { Mode of } \\
\text { administration }\end{array}$ & $\begin{array}{l}\text { Duration of } \\
\text { administration } \\
\text { in days }\end{array}$ & Efficiency \\
\hline $\begin{array}{l}\text { Chatzikyrkou } \\
\text { et al. [26] }\end{array}$ & $\begin{array}{l}\text { Diabetic } \\
\text { ulcers }\end{array}$ & 30 & $\mathrm{~s} / \mathrm{c}$ & 84 & $\boldsymbol{\Delta}$ \\
\hline $\begin{array}{l}\text { Guenter } \\
\text { et al. [27] }\end{array}$ & $\begin{array}{l}\text { Burn } \\
\text { wounds }\end{array}$ & 150 & $s / c$ & 21 & $=$ \\
\hline Hamed [29] & $\begin{array}{l}\text { Diabetic } \\
\text { ulcers }\end{array}$ & 2000 & topically & 84 & $\Delta$ \\
\hline Ferri [30] & $\begin{array}{l}\text { Skin } \\
\text { ulcers }\end{array}$ & 150 & $s / c$ & 56 & $\Delta$ \\
\hline Giri [31] & $\begin{array}{l}\text { Diabetic } \\
\text { ulcers }\end{array}$ & 2000 & Topically & $\begin{array}{l}21 \\
175\end{array}$ & $\Delta$ \\
\hline Keast [32] & $\begin{array}{l}\text { Pressure } \\
\text { ulcers }\end{array}$ & 75 & $s / c$ & $\begin{array}{l}63 \\
42\end{array}$ & $\Delta$ \\
\hline
\end{tabular}


An understanding of the basic molecular mechanisms associated with tissue regeneration with EPO will facilitate the widespread clinical use of this hormone for wound healing.

\section{Conclusion}

The use of the glycoprotein hormone EPO in the context of animal studies has providing tissue and cellular protection, pro-angiogenic, and antiinflammatory activity on all stages of the wound healing process. A few clinical trials identified a positive effect of EPO on skin regeneration it may be a promising therapeutic strategy for the healing of chronic wounds. Treatment by EPO has shown itself as a bright future for efficient wound regeneration. However, more RCT and systematic reviews are needed to better our understanding of limitations and benefits associated with the clinical use of EPO. Further research on regenerative properties of EPO is essential to improve patient care and may reduce the substantial burden of chronic wounds.

\section{References}

1. Peng B, Kong G, Yang C, Ming Y. Erythropoietin and its derivatives: From tissue protection to immune regulation. Cell Death Dis. 2020;11:79. https://doi.org/10.1038/ s41419-020-2276-8

2. Suyono $H$, Sanjaya $K$, Susanti D. The role of antiapoptotic erythropoietin on ultraviolet B-induced photodamaged skin through inhibition of sunburn cells. Fol Med Indones. 2020;56(2):2114-7. https://doi.org/10.20473/fmi.v56i2.21229

3. French $\mathrm{C}$. Erythropoietin in critical illness and trauma. Crit Care Clin. 2019;35(2):277-87 PMid:30784609

4. Chamorro ME. Role of protein tyrosine phosphatase 1B (PTP1B) in the increased sensitivity of endothelial cells to a promigratory effect of erythropoietin in an inflammatory environment. Biol Chem. 2020;401(10):1167-80. https://doi. org/10.1515/hsz-2020-0136

PMid:32386183

5. Lee YM, Choi JH, Min WK, Han JK, Oh JW. Induction of functional erythropoietin and erythropoietin receptor gene expression by gamma-aminobutyric acid and piperine in kidney epithelial cells. Life Sci. 2018;215(15):207-15. https://doi. org/10.1016/j.lfs.2018.11.024

PMid:30439377

6. Kimáková $P$, Solár $P$, Solárová $Z$, Komel $R$, Debeljak $N$. Erythropoietin and its angiogenic activity. Int $\mathrm{J} \mathrm{Mol} \mathrm{Sci.}$ 2017;18(7):1519. https://doi.org/10.3390/ijms1807151912 PMid:28703764

7. Teramo KA, Klemetti MM, Widness JA. Robust increases in erythropoietin production by the hypoxic fetus is a response to protect the brain and other vital organs. Pediatr Res.
2018;84(6):807-12. https://doi.org/10.1038/s41390-018-0054-4 PMid:29895839

8. Collino M, Thiemermann C, Cerami A, Brines M. Flipping the molecular switch for innate protection and repair of tissues: Long-lasting effects of a non-erythropoietic small peptide engineered from erythropoietin. Pharmacol Ther. 2015;151:3240. https://doi.org/10.1016/j.pharmthera.2015.02.005

PMid:25728128

9. Hamed S, Ullmann Y, Egozi D, Keren A, Daod E, Anis O, et al Topical erythropoietin treatment accelerates the healing of cutaneous burn wounds in diabetic pigs through an aquaporin3-dependent mechanism. Diabetes. 2017;66(8):2254-65. https://doi.org/10.2337/db16-1205

PMid:28546424

10. Siebert N, Xu W, Grambow E, Zechner D, Vollmar B. Erythropoietin improves skin wound healing and activates the TGF- $\beta$ signaling pathway. Lab Invest. 2011;91(12):1753-65. https://doi.org/10.1038/labinvest.2011.125 PMid:21894148

11. Javadmoosavi $S \mathrm{Y}$, Parsamanesh $\mathrm{N}$, Afshar $\mathrm{M}$, Zardast $\mathrm{M}$, Ghaderi R. Comparison of the effects of systemic and subcutaneous injection of recombinant human erythropoietin on the tissue-healing process in BALB/c Mice. J Surg Trauma. 2020;8(1):16-22. https://doi.org/10.32592/jsurgery.2020.8.1.102

12. Sayan H, Ozacmak VH, Guven A, Aktas RG, Ozacmak ID. Erythropoietin stimulates wound healing and angiogenesis in mice. J Invest Surg. 2006;19(3):163-73. https://doi. org/10.1080 / 08941930600674694 PMid:16809226

13. Bader A, Ebert S, Giri S, Kremer M, Liu S, Nerlich A, et al. Skin regeneration with conical and hair follicle structure of deep second-degree scalding injuries via combined expression of the EPO receptor and beta common receptor by local subcutaneous injection of nanosized rhEPO. Int J Nanomed. 2012;7:1227-37. https://doi.org/10.2147/ijn.s28186

PMid:22419870

14. Erbayraktar Z, Erbayraktar S, Yilmaz O, Cerami A, Coleman T, Brines M. Nonerythropoietic tissue protective compounds are highly effective facilitators of wound healing. Mol Med. 2009;15(78):235-41. https://doi.org/10.2119/molmed.2009.00051 PMid:19593407

15. Bodó E, Kromminga A, Funk W, Laugsch M, Duske $U$, Jelkmann W, et al. Human hair follicles are an extrarenal source and a nonhematopoietic target of erythropoietin. FASEB J. 2007;21(12):3346-54. https://doi.org/10.1096/fj.07-8628com PMid: 17540710

16. Paus R, Bodó E, Kromminga A, Jelkmann W. Erythropoietin and the skin: A role for epidermal oxygen sensing? Bioessays. 2009;31(3):344-8. https://doi.org/10.1002/bies.200800192 PMid:19260015

17. Buemi M, Galeano M, Sturiale A, lentile R, Crisafulli C, Parisi A, etal. Recombinanthuman erythropoietin stimulates angiogenesis and healing of ischemic skin wounds. Shock. 2004;22(2):16973. https://doi.org/10.1097 / 01.shk.0000133591.47776.bd PMid:15257091

18. Galeano M, Altavilla D, Cucinotta D, Russo GT, Calò M, Bitto $A$, et al. Recombinant human erythropoietin stimulates angiogenesis and wound healing in the genetically diabetic mouse. Diabetes. 2004;53(9):2509-17. https://doi.org/10.2337/ diabetes.53.9.2509 PMid:15331568

19. Hamed S, Ullmann Y, Egozi D, Daod E, Hellou E, Ashkar M, et al. Fibronectin potentiates topical erythropoietin-induced wound repair in diabetic mice. J Invest Dermatol. 2011;131(6):1365-75. https://doi.org/10.1038/jid.2011.15 
PMid:21326299

20. Imam RA, Rizk AA. Efficacy of erythropoietin-pretreated mesenchymal stem cells in murine burn wound healing: Possible in vivo transdifferentiation into keratinocytes. Folia Morphol (Warsz). 2019;78(4):798-808. https://doi.org/10.5603/ fm.a2019.0038

PMid:30949996

21. Holderfield MT, Hughes CC. Crosstalk between vascular endothelial growth factor, notch, and transforming growth factorbeta in vascular morphogenesis. Circ Res. 2008;102(6):637-52. https://doi.org/10.1161/circresaha.107.167171

PMid:18369162

22. Corwin HL, Gettinger A, Fabian TC, May A, Pearl RG, Heard S, et al. Efficacy and safety of epoetin alfa in critically ill patients. N Engl J Med. 2007;357(10):965-76. https://doi.org/10.1056/ nejmoa071533

PMid:17804841

23. Brines M, Patel NS, Villa P, Brines C, Mennini T, De Paola M, et al. Nonerythropoietic, tissue-protective peptides derived from the tertiary structure of erythropoietin. Proc Natl Acad Sci U S A. 2008;105(31):10925-30. https://doi.org/10.1073/ pnas.0805594105

PMid:18676614

24. Bor-Kucukatay M, Yalcin O, Meiselman HJ, Baskurt OK. Erythropoietin-induced rheological changes of rat erythrocytes. $\mathrm{Br} J$ Haematol. 2000;110(1):82-8. https://doi. org/10.1046/j.1365-2141.2000.02150.x

PMid:10930982

25. Kwaan HC, Wang J. Hyperviscosity in polycythemia vera and other red cell abnormalities. Semin Thromb Hemost. 2003;29(5):451-8. https://doi.org/10.1055/s-2003-44552

PMid:14631544

26. Chatzikyrkou C, Bahlmann FH, Sushakova N, Scurt FG,
Menne J, Nawroth P, et al. Low-dose erythropoietin promotes wound-healing of ulcers in diabetics: Evidence from a phase-lla clinical study. Diabetes Metab. 2016;42(6):466-70. http://dx.doi. org/10.1016/j.diabet.2016.05.010

PMid:27324461

27. Günter Cl, Machens HG, Ilg FP, Hapfelmeier A, Jelkmann W, Egert-Schwender $\mathrm{S}$, et al. A randomized controlled trial: Regenerative effects, efficacy and safety of erythropoietin in burn and scalding injuries. Front Pharmacol. 2018;9:951. https://doi.org/10.3389/fphar.2018.00951 PMid:30429786

28. Hamed S, Belokopytov M, Ullmann Y, Safadi M, Stark Y, Shoufani $A$, et al. Interim results of the remede d'Or study: A multicenter, single-blind, randomized, controlled trial to assess the safety and efficacy of an innovative topical formulation of erythropoietin for treating diabetic foot ulcers. Adv Wound Care (New Rochelle). 2019;8(10):514-21. https://doi.org/10.1089/ wound.2018.0808

PMid:31832270

29. Ferri C, Giuggioli D, Sebastiani M, Colaci M. Treatment of severe scleroderma skin ulcers with recombinant human erythropoietin. Clin Exp Dermatol. 2007;32(3):287-90. https:// doi.org/10.1111/j.1365-2230.2007.02363.x PMid:17397351

30. Günter Cl, Kern L, Giri S, Machens HG, Bader A. First results on three patients treated with topical recombinant human erythropoietin (rhEPO) to improve wound healing in diabetic foot ulcers. J Transplant Stem Cell Biol. 2015;2(1):2-5. https://doi. org/10.13188 / 2374-9326.1000007

31. Keast DH, Fraser C. Treatment of chronic skin ulcers in individuals with anemia of chronic disease using recombinant human erythropoietin (EPO): A review of four cases. Ostomy Wound Manage. 2004;50(10):64-70.

PMid:15509883 